\title{
Soil Phosphorus Dynamics of Wheat-Based Cropping Systems in the Semiarid Region of Argentina
}

\author{
Liliana Suñer, ${ }^{1,2}$ Juan Galantini, ${ }^{1}$ and Gabriela Minoldo ${ }^{2}$ \\ ${ }^{1}$ Comisión de Investigaciones Científicas (CIC), CERZOS-UNS, 8000 Bahía Blanca, Argentina \\ ${ }^{2}$ Departamento de Agronomía, Universidad Nacional del Sur, 8000 Bahía Blanca, Argentina
}

Correspondence should be addressed to Liliana Suñer; 1suner@criba.edu.ar

Received 25 July 2013; Revised 17 September 2013; Accepted 21 October 2013; Published 23 January 2014

Academic Editor: Rafael Clemente

Copyright (C) 2014 Liliana Suñer et al. This is an open access article distributed under the Creative Commons Attribution License, which permits unrestricted use, distribution, and reproduction in any medium, provided the original work is properly cited.

\begin{abstract}
The dynamics of soil P forms and particle size fractions was studied under three wheat-based cropping sequences in production systems of Argentina. The whole soil and its coarse $(100-2000 \mu \mathrm{m})$ and fine $(0-100 \mu \mathrm{m})$ fractions were analyzed to determine Bray-Kurtz extractable (Pe), organic (Po), inorganic (Pi), and total (Pte) phosphorus. The reference soil was determined at time 0 and compared to a four-year period (time 9 to 12) in three crop sequences: wheat (Triticum aestivum L.)-cattle grazing on natural grasses (WG), continuous wheat (WW), and wheat-legume (WL). Levels of Pe showed differences over time, from 10 to $16 \mu \mathrm{g} \mathrm{g}^{-1}$ in WG, in line with agriculture and cattle grazing alternate sequences. In WW, P level increased with time, while in WL systems a significant decrease in $\mathrm{P}$ from 33.7 to $10.4 \mu \mathrm{g} \mathrm{P} \mathrm{g}^{-1}$ was found during the legume period. Soil $\mathrm{P}$ values varied between reference soil and soil samples in year nine and between treatments. Pi was significantly lower in WW, and its concentration increased with time. The coarse fraction of the reference plots had significantly higher levels of Po and Pi than the cultivated treatments, probably a consequence of the particulate organic matter decomposition and coarse mineral particle weathering. The observed changes in $\mathrm{Pi}$ content could be attributed to differences in occluded $\mathrm{P}$ equilibrium under different soil environments (mainly $\mathrm{pH}$ ) and croptillage-climatic interaction.
\end{abstract}

\section{Introduction}

Plants absorb mainly inorganic phosphorus (Pi) but the organic phosphorus (Po) is also an important reservoir for plant nutrition $[1,2]$. Several studies have reported reduction in soil organic P fraction during crop growth $[3,4]$. The Po can be found in chemically or physically protected forms, which can be slowly mineralized into available forms for plant uptake, mainly as a product of soil organic matter (SOM) decomposition or by the action of specific enzymes $[5,6]$. A continuous loss of the soil $\mathrm{P}$ reservoir due to crop harvesting can rapidly consume $\mathrm{Po}$ and $\mathrm{Pi}$ forms $[5,7,8]$, which may eventually lead to plant $\mathrm{P}$ deficiencies.

Several soil studies have shown $\mathrm{P}$ deficiencies in the semiarid and semihumid regions of Argentina, and that extractable $\mathrm{P}$ content is lower due to soil pedogenetic characteristics and the agricultural history of the region [9-11]. Agricultural and cattle breeding systems of the semiarid Pampas region revealed negative $\mathrm{P}$ balances [12]. While $\mathrm{P}$ in the soil has been widely studied, little information is available on its organic fractions [13]. In the western area of the Province of Buenos Aires, Po represents between 29\% and $51 \%$ of the total $\mathrm{P}$ reserve [14]. Soil total phosphorus $(\mathrm{Pt})$ reserve from the soil largely exceeds crop requirements, however plants could suffer deficiencies. Thus, the ability of soils to provide $\mathrm{P}$ can be variable. While soil $\mathrm{Pt}$ content in the soil may be relatively high $\left(200\right.$ to $\left.5000 \mu \mathrm{g} \mathrm{g}^{-1} ;[8,15]\right)$ only a small and variable fraction is available for crops. This may vary from 5 to $20 \mu \mathrm{g} \mathrm{P} \mathrm{g}^{-1}$ in Pampaean soils [10]. However deficiencies do not take place when the soils contain adequate quantities of plant-available or rapidly usable P forms (such as fertilizers or labile organic $\mathrm{P}$ compounds).

McKenzie et al. [16] found that the wheat (Triticum aestivum L.)-fallow sequence was the most effective for Po mineralization. When a legume crop was added to the cropping rotation, soil Pi values decreased [17]. Some studies $[18,19]$ quantified soil Po and Pi contents in the soils, others analyzed their dynamics over time [8], but little information is available about their distribution in different soil particle sizes and their relationship with the available $\mathrm{P}$. 
The P compounds strongly bound to soil fine fraction have been shown to be unaffected by tillage treatments [14, 20]. Phosphorus in the coarse fraction, however, sharply decreases due to cultivation. Results of these studies suggested that the greater decomposition of the SOM in the coarse fraction facilitated availability of Po and Pi for subsequent crops. Particle size fractions of SOM may help characterize nutrient dynamics and soil quality status [6]. Understanding Po dynamics within the soil system is useful to assess $\mathrm{P}$ availability and to avoid excessive fertilization with undesirable environmental consequences [21, 22]. In addition, quantification of $\mathrm{P}$ mineralization in different environment-management conditions will allow the inclusion of true data in the simulation models [23].

When organic and inorganic phosphorus are determined, in both fine and coarse fractions, it will expect that Po content in the coarse fraction would be the most sensitive to crop-tillage management changes. This Po is associated with particulate organic matter, a labile SOM fraction. However, Pi content in the coarse fraction would be more stable because of its relationship with sand size. On the other hand, Po content in the fine fraction would be stable because of its relationship with humified organic materials, while the Pi content would be more strongly linked to plant $\mathrm{P}$ availability due to its relationship with fine size minerals of soil.

We hypothesized that crop sequences can modify the $\mathrm{P}$ distribution within different soil particle sizes, affecting its availability for plants. The main objective of this study was to evaluate the changes caused by different wheat-based cropping sequences on the distribution of $\mathrm{P}$ forms in particle size fractions in an entic Haplustoll of the semiarid Pampas.

\section{Materials and Methods}

This study was carried out at the Agricultural Experimental Research Station of INTA, Bordenave $\left(63^{\circ} 01^{\prime} 20^{\prime \prime} \mathrm{W}\right.$ and $37^{\circ}$ $\left.51^{\prime} 55^{\prime \prime} \mathrm{S}\right)$, Province of Buenos Aires, Argentina. The climate in this area is temperate (continental moderated), with a mean annual temperature of $15^{\circ} \mathrm{C}$. Mean annual rainfall is about $667 \mathrm{~mm}$ (1928-2013), concentrated in autumn and spring, with a dry period at the end of the winter and semidry period in the middle of summer. During the studied period mean annual precipitation was around $900 \mathrm{~mm}$. Mean annual evapotranspiration rate is $28 \%$ more than the climatic offer. The main soil subgroup is entic Haplustoll (FAO: Haplic Kastanozem), which is a thermal, sandy loam, typically of this region, which has low to medium fertility and is sensitive to wind erosion, with a calcareous layer located between 0.8 and $1.0 \mathrm{~m}$ in depth [24]. Three cropping sequences were established on 12 ha of pasture land in 1983. They included:

(i) WG, one year wheat and one year cattle grazing on natural grasses (Lolium sp., Avena sp., and other weeds). Wheat was in conventional tillage: short or without fallow; disk plough (0.15-0.20 m) and harrowing; regular seeding at $4-5 \mathrm{~cm}$ deep.

(ii) WW, continuous wheat. Following harvest, there was a 4-6-month fallow (January-June) under stubble mulch used for soil moisture storage, mechanical
TABLE 1: Crop sequences in the studied production systems and mean annual rainfall.

\begin{tabular}{lcccc}
\hline $\begin{array}{l}\text { Years from } \\
\text { the beginning }\end{array}$ & WG & WW & WL & $\begin{array}{c}\text { Annual rainfall } \\
(\mathrm{mm})\end{array}$ \\
\hline 0 & & & & \\
1 & Grass/oat & Wheat & Wheat & 683.7 \\
2 & Wheat & Wheat & Wheat & 998.1 \\
3 & Grass/oat & Wheat & Wheat & 965 \\
4 & Wheat & Wheat & Red clover & 611.9 \\
5 & Grass & Wheat & Red clover & 781.8 \\
6 & Wheat & Wheat & Red clover & 647.1 \\
7 & Grass & Wheat & Wheat & 697.1 \\
8 & Wheat & Wheat & Wheat & 612 \\
9 & Grass & Wheat & Wheat & 1194.7 \\
10 & Wheat & Wheat & Red clover & 1108.3 \\
11 & Grass & Wheat & Red clover & 678.9 \\
12 & Wheat & Wheat & Red clover & 641.6 \\
\hline
\end{tabular}

Wheat (Triticum aestivum); red clover (Trifolium repens).

weed control using chisel ploughing to a depth of $0.20 \mathrm{~m}$ preceded wheat deep-furrow seeding, which deposits the seed $8-10 \mathrm{~cm}$ deep.

(iii) WL, 3 years of wheat and 3 years of red clover (Trifolium repens). Tillage was the same as WW rotation.

Crop sequence for each cropping system is shown in Table 1. A reference (Ref) plot adjacent to treatments was maintained with native grasses for over 25 years. Fertilizers were not applied in any of the rotations.

Surface soil samples $(0-15 \mathrm{~cm}$ depth) were obtained after wheat growing cycle during November of each sampling year; 3 subsampling points were located using GPS for subsequent sampling. Three blocks were randomly located in the three production systems and in reference soil; three composite samples consisting of three soil sample each were obtained from each block. Soil texture differences were not observed between different blocks or treatments, with mean values for clay and silt of 101 and $218 \mathrm{~g} \mathrm{~kg}^{-1}$, respectively. The samples were returned to the lab, air dried, sieved $(<2 \mathrm{~mm})$, and stored for analysis. Soil was sampled 9 years after initiating crop rotations and the subsequent years.

2.1. Soil Chemical Determinations. Soil $\mathrm{pH}$ with a glass electrode at a 1:2.5 water ratio [25], total soil organic carbon (SOC) by dry combustion (LECO carbon analyzer), and the following $\mathrm{P}$ forms were determined:

(i) extractable (Pe) by Bray-Kurtz 1 [26]: extraction with hydrochloric acid $(\mathrm{HCl}) 0.025 \mathrm{M}$ and ammonium fluoride $\left(\mathrm{NH}_{4} \mathrm{~F}\right) 0.03 \mathrm{M}$ ( $\left.\mathrm{pH} 2.9\right)$, soil/solution ratio $1: 7$, shaking time $1 \mathrm{~min}$; this method is indicated for soils with neutral to slightly acidic $\mathrm{pH}$ [27];

(ii) total extractable (Pte), [28] with a perchloric acid digestion to $270^{\circ} \mathrm{C}$;

(iii) total $(\mathrm{Pt})$ with sodium carbonate [29]; 0.1-1 g sample is fussed in sodium carbonate $\left(\mathrm{Na}_{2} \mathrm{CO}_{3}\right)$ to $900^{\circ} \mathrm{C}$ 
TABLE 2: Soil organic carbon (SOC), organic (Po), inorganic (Pi), total extractable (Pte), total and extractable phosphorus (Pe), Po : (Po + Pi) relationships, and $\mathrm{pH}$ of different cropping systems (CS).

\begin{tabular}{|c|c|c|c|c|c|c|c|c|c|}
\hline Year & CS & $\begin{array}{c}\text { SOC } \\
\%\end{array}$ & \multicolumn{2}{|c|}{$\mathrm{mg} \mathrm{kg}^{-1}$} & $\mathrm{Po}:(\mathrm{Po}+\mathrm{Pi})$ & Pte & $\begin{array}{c}\mathrm{Pt} \\
\mathrm{mg} \mathrm{kg}^{-1}\end{array}$ & $\mathrm{Pe}$ & $\mathrm{pH}$ \\
\hline \multirow[t]{2}{*}{0} & Ref & 1.28 & 189.0 & 328.0 & 0.37 & 529.0 & 562.1 & 30.9 & 6.7 \\
\hline & WG & $1.13^{\mathrm{a} *}$ & $77.7^{\mathrm{a} * *}$ & $294.7^{\mathrm{a} *}$ & $0.20^{\mathrm{a} * *}$ & $289.6^{\mathrm{b} * *}$ & $412.2^{\mathrm{b} *}$ & $14.3^{\mathrm{b} * *}$ & $6.8^{\mathrm{a}} \mathrm{ns}$ \\
\hline \multirow[t]{3}{*}{9} & WW & $0.89^{\mathrm{b} * *}$ & $50.4^{\mathrm{b} * *}$ & $172.0^{\mathrm{b} * *}$ & $0.22^{\mathrm{a} * *}$ & $230.0^{\mathrm{b} * *}$ & $396.3^{\mathrm{b} *}$ & $11.7^{\mathrm{b} * *}$ & $6.6^{\mathrm{b}} \mathrm{ns}$ \\
\hline & WL & $1.14^{\mathrm{a} *}$ & $82.2^{\mathrm{a} * *}$ & $290.5^{\mathrm{a} *}$ & $0.22^{\mathrm{a} * *}$ & $417.3^{\mathrm{a} *}$ & $456.3^{\mathrm{a} *}$ & $33.7^{\mathrm{a}} \mathrm{ns}$ & $6.6^{\mathrm{b}} \mathrm{ns}$ \\
\hline & WG & $1.08^{\mathrm{a}}$ & $133.7^{\mathrm{a}}$ & $231.1^{\mathrm{a}}$ & $0.37^{\mathrm{a}}$ & $396.7^{\mathrm{a}}$ & $418.0^{\mathrm{a}}$ & $10.2^{\mathrm{b}}$ & $6.4^{\mathrm{ab}}$ \\
\hline \multirow[t]{3}{*}{10} & WW & $0.84^{\mathrm{b}}$ & $75.5^{\mathrm{b}}$ & $159.0^{\mathrm{b}}$ & $0.32^{\mathrm{b}}$ & $344.1^{\mathrm{b}}$ & $378.2^{\mathrm{ab}}$ & $13.1^{\mathrm{b}}$ & $6.3^{\mathrm{b}}$ \\
\hline & WL & $1.11^{\mathrm{a}}$ & $107.3^{\mathrm{ab}}$ & $230.5^{\mathrm{a}}$ & $0.32^{\mathrm{b}}$ & $339.7^{\mathrm{b}}$ & $362.1^{\mathrm{b}}$ & $21.2^{\mathrm{a}}$ & $6.5^{\mathrm{a}}$ \\
\hline & WG & $1.07^{\mathrm{a}}$ & 86.7 & $217.5^{\mathrm{b}}$ & $0.38^{\mathrm{a}}$ & $350.2^{\mathrm{a}}$ & $440.0^{\mathrm{a}}$ & $15.7^{\mathrm{b}}$ & $6.3^{\mathrm{a}}$ \\
\hline \multirow[t]{3}{*}{11} & WW & $0.85^{\mathrm{b}}$ & 84.0 & $176.3^{\mathrm{c}}$ & $0.32^{\mathrm{b}}$ & $316.8^{\mathrm{b}}$ & $407.2^{\mathrm{a}}$ & $18.8^{\mathrm{b}}$ & $6.3^{\mathrm{a}}$ \\
\hline & WL & $1.12^{\mathrm{a}}$ & 81.5 & $245.7^{\mathrm{a}}$ & $0.33^{\mathrm{b}}$ & $289.7^{\mathrm{b}}$ & $328.4^{\mathrm{b}}$ & $26.0^{\mathrm{a}}$ & $6.1^{\mathrm{b}}$ \\
\hline & WG & $1.16^{\mathrm{a}}$ & 85.4 & $218.1^{\mathrm{b}}$ & $0.28^{\mathrm{a}}$ & $343.0^{\mathrm{a}}$ & $420.0^{\mathrm{a}}$ & $11.6^{\mathrm{b}}$ & $6.4^{\mathrm{a}}$ \\
\hline \multirow[t]{2}{*}{12} & WW & $0.95^{\mathrm{b}}$ & 65.7 & $233.7^{\mathrm{ab}}$ & $0.22^{\mathrm{b}}$ & $365.2^{\mathrm{a}}$ & $411.3^{\mathrm{a}}$ & $27.2^{\mathrm{a}}$ & $6.1^{\mathrm{b}}$ \\
\hline & WL & $1.27^{\mathrm{a}}$ & 78.3 & $250.2^{\mathrm{a}}$ & $0.24^{\mathrm{b}}$ & $280.1^{b}$ & $321.6^{\mathrm{b}}$ & $10.4^{\mathrm{b}}$ & $6.2^{\mathrm{b}}$ \\
\hline
\end{tabular}

**, ${ }^{*}$ and ns indicate statistical differences $P<0.01, P<0.05$ and not significant, respectively, between each treatment sampled in year 9 and reference soil. For SOC, each $\mathrm{P}$ form and $\mathrm{pH}$, different letters indicate differences among treatments in each year.

followed by disintegration of the melt in clorhidric acid $(\mathrm{HCl})$;

(iv) and organic (Po) and inorganic (Pi) by Saunders and Williams [30] method extraction with sulphuric acid $\left(\mathrm{H}_{2} \mathrm{SO}_{4}\right) 1 \mathrm{~N}$, shaking time 16 hours; Po is determined by difference between a calcined soil sample (in muffle to $550^{\circ} \mathrm{C}$ ) and another one without calcine.

Inorganic $\mathrm{P}$ in all extracts was determined by the ammonium vanadate colorimetric method [31]. All these methods are fully described in Sparks [32].

2.2. Soil Physical Determinations. For the size fractionation of soil, we used the wet sieving of soil $[33,34]$. Briefly, $50 \mathrm{~g}$ of soil previously air-dried and sieved $(2 \mathrm{~mm})$ was dispersed in glass containers of $120 \mathrm{~mL}$ and mixed with $100 \mathrm{~mL}$ of distilled water. Ten glass beads ( $5 \mathrm{~mm}$ diameter) were added to increase aggregate destruction and reduce potential problems created by different content of sand [33]. The samples were subjected to mechanical dispersion through a rotary shaker for approximately $16 \mathrm{~h}$ (overnight at $40 \mathrm{rpm}$ ) to disintegrate the aggregates. The sieving was done with a sieve of $140 \mathrm{mesh}$, making moves back and forth until the water coming out through the sieve was clear to the naked eye. Two particle size fractions were obtained: the fine fraction $(0-100 \mu \mathrm{m})$ and the coarse $(100-2000 \mu \mathrm{m})$, both fractions were oven-dried at $65^{\circ} \mathrm{C}$. The fine fraction contained clay, silt, very fine sands, and humified or mineral associated organic matter (MOM). The coarse fraction had sand and less transformed, young, or particulate organic matter (POM). The same chemical methods above were also applied to determinate Pte, Po, and $\mathrm{Pi}$ in both fractions. Pe was not determinate in the fractions because physical separation of the particles could wash some available P forms [20].

2.3. Statistical Analysis. Statistical analysiswas performed using analysis of the variance (ANOVA) and InfoStat's least significant differences (LSD) procedure [23].
Comparisons among years were not made due to significant interactions over time, probably as a consequence of the crop-rainfall interaction. For that reason, the statistical analysis was performed in two ways: (1) by comparing the Ref soil with each treatment in year 9 and (2) by comparing the three treatments in each year $(9,10,11$, and 12 years).

\section{Results}

3.1. Soil Phosphorus. Soil organic and inorganic P concentrations decreased under the different cropping sequences with a sharp decline in the $\mathrm{Po}:(\mathrm{Po}+\mathrm{Pi})$ ratio. Inorganic $\mathrm{P}$ was the most abundant form in both the reference and cultivated soils (Table 2). Soil Pi content was significantly lower in WW than in WG and WL. The Pte concentration (perchloric extraction) showed lower concentrations in cultivated than in the reference soil and variability was high among treatments and years. In comparison the Pt concentration $\left(\mathrm{Na}_{2} \mathrm{CO}_{3}\right.$ digestion) showed low variability among soils and years. Different trends were observed in the variation of the Pe among the years in the analyzed cropping systems (Table 2). The $\mathrm{pH}$ showed differences among treatments.

3.2. Particle Size Fraction P. After years with different cropping systems, the Po in the fine fraction was stable among treatments throughout sampling years (Table 3 ). The Pi in the same fraction was significantly lower in $\mathrm{WW}$ than in WG and WL treatments. This difference did not change the next sampling years. The Pte in the fine fraction of all three treatments was different during the first year but there were no statistical significant differences in later years.

The most important changes in Po and Pi contents in coarse fractions were found between the reference soil and the treatments, mainly due to the Po content depletion (Table 3). Statistical differences over time were observed in the inorganic $\mathrm{P}$ forms, which tended to disappear with time. These differences were only found in Pi content under WW during the first three sampling years. 
TABLE 3: Soil organic (Po), inorganic (Pi), and total extractable phosphorus (Pte) in the fine and coarse fraction of different cropping systems (CS).

\begin{tabular}{|c|c|c|c|c|c|c|c|}
\hline \multirow[t]{2}{*}{ Year } & \multirow[t]{2}{*}{ CS } & \multicolumn{3}{|c|}{$\begin{array}{c}\text { Fine fraction } \\
\mathrm{mg} \mathrm{kg}^{-1}\end{array}$} & \multicolumn{3}{|c|}{$\begin{array}{c}\text { Coarse fraction } \\
\mathrm{mg} \mathrm{kg}^{-1}\end{array}$} \\
\hline & & Po & $\mathrm{Pi}$ & Pte & Po & $\mathrm{Pi}$ & Pte \\
\hline \multirow[t]{2}{*}{0} & Ref & 60.0 & 178.0 & 329.0 & 129.0 & 149.0 & 199.0 \\
\hline & WG & $72.1^{\mathrm{b}} \mathrm{ns}$ & $199.8^{\mathrm{a} *}$ & $221.5^{\mathrm{b} * *}$ & $5.6^{\mathrm{a} * *}$ & $95.2^{a * *}$ & $98.1^{a * *}$ \\
\hline \multirow[t]{3}{*}{9} & WW & $50.0^{\mathrm{c}} \mathrm{ns}$ & $98.4^{\mathrm{b} * *}$ & $149.7^{\mathrm{c} * *}$ & $2.1^{\mathrm{a} * *}$ & $73.6^{\mathrm{b} * *}$ & $80.2^{\mathrm{b} * *}$ \\
\hline & WL & $88.1^{\mathrm{a} *}$ & $200.8^{\mathrm{a} *}$ & $331.4^{\mathrm{a}} \mathrm{ns}$ & $1.2^{\mathrm{a} * *}$ & $89.7^{\mathrm{a} * *}$ & $85.9^{\mathrm{b} * *}$ \\
\hline & WG & $127.8^{\mathrm{a}}$ & $149.6^{\mathrm{a}}$ & $305.7^{\mathrm{a}}$ & $6.1^{\mathrm{a}}$ & $81.5^{\mathrm{a}}$ & $91.0^{\mathrm{a}}$ \\
\hline \multirow[t]{3}{*}{10} & WW & $72.2^{\mathrm{b}}$ & $93.8^{\mathrm{b}}$ & $256.3^{\mathrm{b}}$ & $3.3^{\mathrm{a}}$ & $65.2^{\mathrm{b}}$ & $87.8^{\mathrm{a}}$ \\
\hline & WL & $101.6^{\mathrm{a}}$ & $144.3^{\mathrm{a}}$ & $263.2^{\mathrm{ab}}$ & $5.7^{\mathrm{a}}$ & $86.2^{\mathrm{a}}$ & $76.5^{\mathrm{b}}$ \\
\hline & WG & $75.4^{\mathrm{a}}$ & $143.4^{\mathrm{a}}$ & $264.0^{\mathrm{a}}$ & $17.5^{\mathrm{a}}$ & $74.1^{\mathrm{b}}$ & $86.2^{\mathrm{a}}$ \\
\hline \multirow[t]{3}{*}{11} & WW & $75.4^{\mathrm{a}}$ & $121.0^{\mathrm{b}}$ & $239.5^{\mathrm{ab}}$ & $6.8^{\mathrm{a}}$ & $55.3^{\mathrm{c}}$ & $77.3^{\mathrm{b}}$ \\
\hline & WL & $77.6^{\mathrm{a}}$ & $151.5^{\mathrm{a}}$ & $207.9^{\mathrm{b}}$ & $8.9^{\mathrm{a}}$ & $94.1^{\mathrm{a}}$ & $81.8^{\mathrm{ab}}$ \\
\hline & WG & $84.8^{\mathrm{a}}$ & $133.9^{b}$ & $259.2^{\mathrm{a}}$ & $1.6^{\mathrm{a}}$ & $84.2^{\mathrm{a}}$ & $83.8^{\mathrm{a}}$ \\
\hline \multirow[t]{2}{*}{12} & WW & $57.9^{\mathrm{b}}$ & $150.7^{\mathrm{ab}}$ & $256.6^{\mathrm{ab}}$ & $8.6^{\mathrm{a}}$ & $83.0^{\mathrm{a}}$ & $108.5^{\mathrm{b}}$ \\
\hline & WL & $89.3^{\mathrm{a}}$ & $161.6^{\mathrm{a}}$ & $199.0^{\mathrm{b}}$ & $4.3^{\mathrm{a}}$ & $88.7^{\mathrm{a}}$ & $81.1^{\mathrm{a}}$ \\
\hline
\end{tabular}

**, ${ }^{*}$ and ns indicate statistical differences $P<0.01, P<0.05$ and not significant, respectively, between each treatment sampled in year 9 and reference soil. For each $\mathrm{P}$ form different letters indicate differences among treatments in each year.

\section{Discussion}

4.1. Soil Phosphorus. The main differences in $\mathrm{P}$ fraction were observed between reference and cultivated soils. The highest variability of Po with respect to SOC suggests quality variations during crop sequences [6]. However, total SOC, as well as total Po, include fractions of a different quality and dynamics, which will individually be considered.

The effect of continuous wheat with fertilizer application on SOC content was a consequence of annual tillage and low residue input. A grassing period without tillage (WG and WL) and an increased residue input due to biological fixed $\mathrm{N}$ (WL) could explain the higher SOC in WG and WL as compared with WW $[34,35]$.

During the 4-year study period, treatments did not affect the dynamics of the organic P fraction. Other studies on Po in Pampas soils detected slight differences between management systems [36]. The characteristics of the method for Po determination, which estimates Po indirectly, could account for the difficulties in detecting statistical differences in these studies. In the applied method, Po was converted to Pi by high temperature oxidation and it was quantified by difference. Temperature effect on Pi solubility and acid extraction effect on Po hydrolysis could increase data variability [15]. The $\mathrm{Po}:(\mathrm{Po}+\mathrm{Pi})$ ratio showed differences between years and treatments as a consequence of the cropping system characteristics and the rainfall variations during the study period. The abundant rainfalls in the 10th year favored plant uptake and dry matter production, which was reflected in higher $\mathrm{Po}:(\mathrm{Po}+\mathrm{Pi})$ ratios in all treatments as compared with those in other years. The Pte values were more variable and, in some cases, showed differences with Pt values. This suggests that Pte extraction method depended on the soil conditions and physicochemical equilibrium.

Considering that the Po plus Pi quantity ranged between 222 and $373 \mathrm{mg} \mathrm{kg}^{-1}$ and the Pte ranged from 230 to $417 \mathrm{mg} \mathrm{kg}^{-1}$, a variable fraction of the soil $\mathrm{P}$ is not quantified by the Saunders and Williams [30] method. The variations could be related to organo-mineral complexes and would seem to be associated with management practices [33].

After ploughing pasture soils, available P increased over the plant requirements suggesting that physicochemical equilibrium could result in precipitation of inorganic $\mathrm{P}$ forms such as apatite $\left(\mathrm{Ca}_{5}\left(\mathrm{PO}_{4}\right)_{3}(\mathrm{OH}, \mathrm{F}, \mathrm{Cl})\right)$ or brushite $\left(\mathrm{CaHPO}_{4} \cdot 2\left(\mathrm{H}_{2} \mathrm{O}\right)\right)[35,37,38]$. Under similar conditions, Galantini et al. [39] observed a sharp decrease in Pe during the first four years under continuous wheat and a slow increase after the 5th or 6th year. Physicochemical equilibrium of soil $\mathrm{P}$ was climatic (water regime) and management (phosphate status and tillage) dependent. As observed by others, this dynamics could mask biological effects on soil $\mathrm{P}$ changes [40].

In the WG treatment, Pe content ranged from 10 to $16 \mathrm{mg} \mathrm{kg}^{-1}$ over time, showing higher values during grassing than wheat years. In continuous wheat, Pe level increased over time, whereas in WL they decreased significantly, from $33.7 \mathrm{mg} \mathrm{kg}^{-1}$ at the end of the wheat period to $10.4 \mathrm{mg} \mathrm{kg}^{-1}$ at the end of the legume period. A decrease during legume periods was also observed by other authors [17]. Statistical differences in $\mathrm{pH}$ values were observed among treatments in all sampling years. All three cropping systems showed a $\mathrm{pH}$ decrease over time; this might influence the $\mathrm{P}$ balance because a $\mathrm{pH}$ decrease could improve $\mathrm{P}$ solubility favoring flux from inorganic nonlabile to inorganic labile $\mathrm{P}$ forms.

4.2. Particle Size Fraction P. The inherent variability of Po, due to different plant residues and analysis method variability of this organic fraction, due to different plant residues and analysis method variability (obtained by difference between $\mathrm{Pi}$ and $\mathrm{Po}$ plus $\mathrm{Pi}$ ), may explain the difficulty in detecting expected differences among sequences. Nine years under WW produced the lowest Pi content in the fine fraction, but no changes were found in WG and WL cropping systems. During the following sampling times, $\mathrm{Pi}$ concentrations 
tended to increase in $\mathrm{WW}$ and to decrease in WG and WL treatments. The importance of the observed differences would suggest that it might be a consequence of the type and accessibility of $\mathrm{P}$ forms. This observation could be accounted for by the lower variability of Pte values. This increase of $\mathrm{Pi}$ in WW might occur because of the change from inorganic occluded or nondetected P to inorganic available forms, and later quantified in the analysis. In addition, losses due to plant uptake could be compensated with P from the coarse fraction.

More than $95 \%$ of the organic and $35 \%$ of the inorganic $P$ as compared to the reference soil was lost in the coarse fraction due to cultivation. Probably, there was a combined effect of crop sequences (due to $P$ requirement and residue input) and climatic condition effects on crop production and fresh organic matter mineralization [34, 39, 41]. Results revealed that the coarse fraction was mainly altered when the natural pastures were cultivated. Tillage effect on mineral weathering decreases were most likely related to faster decomposition of POM and the tillage influence on particle size and organomineral complex stability [41]. Previous results showed that tillage intensity modified humified SOM quantity and quality [6]. As tillage increases, humic substances decrease in quantity and reactivity. Some of the P changes were due to crop uptake and export through harvest, while other changes were linked to losses from the coarse fraction to the fine fraction by size reduction during tillage activities.

The effect of cropping system on P content in whole soil and its fine and coarse size fractions in a semiarid Haplustoll can be summarized as follows:

(i) The major differences for all P forms were observed when cropping systems were compared with the reference soil.

(ii) Reduction in the $\mathrm{Po}:(\mathrm{Po}+\mathrm{Pi})$ ratio was mainly due to decomposition of SOM and this decomposition rate was dependent on moisture availability.

(iii) The Pe content was modified by cropping system, increasing under a WW sequence and decreasing under WL or WG.

(iv) The main effect of a cropping system on P dynamics was the rapid decomposition of the $\mathrm{P}$ in the soil coarse fraction with an increase of $\mathrm{Pi}$ in the fine fraction.

(v) Soil P distribution depended mainly upon tillage effect on SOM mineralization and particle size distribution, as well as the cropping system and the potential changes in water availability modified physicochemical equilibrium.

\section{Conclusions}

Soil cropping modifies $\mathrm{P}$ distribution within different soil particle sizes. A decrease of the P in coarse fraction (both organic and inorganic forms) was observed. As was hypothesized, crop sequences modify P distribution on soil particle size. The Pi form is mainly affected.

\section{Conflict of Interests}

The authors declare that there is no conflict of interests regarding the publication of this paper.

\section{Acknowledgments}

The authors wish to thank the institutions which provided the funding and personnel for this research to the "Comisión de Investigaciones Científicas" (CIC, Pcia. Bs. As.) and the "Estación Experimental Agropecuaria Bordenave INTA".

\section{References}

[1] J. F. Dormaar and J. M. Carefoot, "Implications of crop residue management and conservation tillage on soil organic matter," Canadian Journal of Plant Science, vol. 76, no. 4, pp. 627-634, 1996.

[2] J. W. B. Stewart and H. Tiessen, "Dynamics of soil organic phosphorus," Biogeochemistry, vol. 4, no. 1, pp. 41-60, 1987.

[3] H. Tiessen, J. W. B. Stewart, and J. R. Bettany, "Cultivation effects on the amounts and concentrations of carbon, nitrogen and phosphorus in grassland soils," Agronomy Journal, vol. 74, pp. 831-835, 1982.

[4] R. A. Bowman, M. F. Vigil, D. C. Nielsen, and R. L. Anderson, "Soil organic matter changes in intensively cropped dryland systems," Soil Science Society of America Journal, vol. 63, no. 1, pp. 186-191, 1999.

[5] W. McNair Bostick, V. B. Bado, A. Bationo, C. T. Soler, G. Hoogenboom, and J. W. Jones, "Soil carbon dynamics and crop residue yields of cropping systems in the Northern Guinea Savanna of Burkina Faso," Soil and Tillage Research, vol. 93, no. 1, pp. 138151, 2007.

[6] M. E. Duval, J. A. Galantini, J. O. Iglesias, S. Canelo, J. M. Martinez, and L. Wall, "Analysis of organic fractions as indicators of soil quality under natural and cultivated systems," Soil and Tillage Research, vol. 131, pp. 11-19, 2013.

[7] A. N. Sharpley and S. J. Smith, "Distribution of phosphorus forms in virgin and cultivated soils and potential erosion losses," Soil Science Society of America Journal, vol. 47, no. 3, pp. 581-586, 1983.

[8] L.-A. Niu, J.-M. Hao, B.-Z. Zhang, and X.-S. Niu, "Influences of long-term fertilizer and tillage management on soil fertility of the north China plain," Pedosphere, vol. 21, no. 6, pp. 813-820, 2011.

[9] T. Loewy and C. A. Purricelli, "Disponibilidad de fósforo en suelos del área de la," EEA no. 28, Bordenave, Argentina, 1982 (Spanish) .

[10] F. García, "Balance de fósforo en los suelos de la región pampeana," Informaciones Agronómicas, no. 9, 2001 (Spanish).

[11] L. Suñer and J. Galantini, "Fertilización fosforada en suelos cultivados con trigo de la región sudoeste pampeana," Ciencia Del Suelo, vol. 30, pp. 57-66, 2012 (Spanish).

[12] E. J. Chaneton, J. H. Lemcoff, and R. S. Lavado, "Nitrogen and phosphorus cycling in grazed and ungrazed plots in a temperate subhumid grassland in Argentina," Journal of Applied Ecology, vol. 33, no. 2, pp. 291-302, 1996.

[13] E. N. Hepper, G. G. Hevia, D. E. Buschiazzo, A. M. Urioste, and A. Bono, "Efectos de la agricultura sobre fracciones de fósforo en suelos de la región semiárida pampeana central," Ciencia del Suelo, vol. 14, no. 2, pp. 96-99, 1996 (Spanish). 
[14] J. A. Galantini and R. A. Rosell, "Organic fractions, N, P and S changes in an Argentine semiarid haplustoll under different crop sequences," Soil and Tillage Research, vol. 42, no. 3, pp. 221228, 1997.

[15] S. Kuo, "Phosphorus," in Methods of Soil Analysis, Part 3- Chemical Methods, D. L. Sparks, A. L. Page, P. A. Helme et al., Eds., pp. 894-895, American Society of Agronomy, Madison, Wis, USA, 1996.

[16] R. H. McKenzie, J. W. B. Stewart, J. F. Dormaar, and G. B. Schaalje, "Long-term crop rotation and fertilizer effects on phosphorus transformations: II. in a Luvisolic soil," Canadian Journal of Soil Science, vol. 72, no. 4, pp. 581-589, 1992.

[17] N. Echeverría, T. Grossi, C. A. Puricelli, and H. Pelta, "Evolución de cuatro parámetros del suelo en dos manejos contrastados," in 14a Congreso Argentino de la Ciencia del Suelo, p. 305, Asociación Argentina de la Ciencia del Suelo, Mendoza, Argentina, 1993 (Spanish).

[18] F. Selles, B. G. McConkey, and C. A. Campbell, "Distribution and forms of $\mathrm{P}$ under cultivator- and zero-tillage for continuous- and fallow-wheat cropping systems in the semi-arid Canadian prairies," Soil and Tillage Research, vol. 51, no. 1-2, pp. 47-59, 1999.

[19] L. M. Zibilske and J. M. Bradford, "Tillage effects on phosphorus mineralization and microbial activity," Soil Science, vol. 168, no. 10, pp. 677-685, 2003.

[20] R. A. Rosell, J. A. Galantini, and L. G. Suñer, "Long-term crop rotation effects on organic carbon, nitrogen, and phosphorus in haplustoll soil fractions," Arid Soil Research and Rehabilitation, vol. 14, no. 4, pp. 309-315, 2000.

[21] I. Saarela, A. Järvi, H. Hakkola, and K. Rinne, "Phosphorus status of diverse soils in Finland as influenced by long-term P fertilisation 2. changes of soil test values in relation to $P$ balance with references to incorporation depth of residual and freshly applied P," Agricultural and Food Science, vol. 13, no. 3, pp. 276294, 2004.

[22] D. S. Powlson, P. J. Gregory, W. R. Whalley et al., "Soil management in relation to sustainable agriculture and ecosystem services," Food Policy, vol. 36, no. 1, pp. 572-587, 2011.

[23] J. A. Di Renzo, F. Casanoves, M. G. Balzarini, L. Gonzalez, M. Tablada, and C. W. Robledo, "Infostat versión 2008," Grupo InfoStat, FCA, Universidad Nacional de Córdoba, Argentina, 2008.

[24] L. Gómez, V. Nakama, and C. Puricelli, "Carta detallada de suelos," EEA, Escala 1:10 000, Bordenave, Argentina, 1981.

[25] G. W. Thomas, "Soil pH and soil acidity," in Methods of Soil Analysis, Part 3- Chemical Methods, D. L. Sparks, A. L. Page, P. A. Helme et al., Eds., pp. 475-490, American Society of Agronomy, Madison, Wis, USA, 1996.

[26] R. H. Bray and L. T. Kurtz, "Determination of total, organic and available forms of phosphorous in soils," Soil Science, vol. 59, pp. 39-45, 1945.

[27] P. Zalba and J. A. Galantini, "Modified soil-test methods for extractable phosphorus in acidic, neutral, and alkaline soils," Communications in Soil Science and Plant Analysis, vol. 38, no. 11-12, pp. 1579-1587, 2007.

[28] L. E. Sommers and D. D. W. Nelson, "Determination of total phosphorus in soil," Soil Science Society of America Proceedings, vol. 36, pp. 902-904, 1972.

[29] M. L. Jackson, Soil Chemical Analysis, Prentice Hall, Englewood Cliffs, NJ, USA, 1958.
[30] W. M. H. Saunders and E. G. Williams, "Observations on the determination of total organic phosphorus in soil," Journal of Soil Science, vol. 6, pp. 254-267, 1955.

[31] J. Murphy and J. P. Riley, "A modified single solution method for the determination of phosphate in natural waters," Analytica Chimica Acta, vol. 27, pp. 31-36, 1962.

[32] A. L. Page, M. E. Sumner, A. Tabatabai et al., Methods of Soil Analysis Part 3-Chemical Methods, American Society of Agronomy, Madison, Wis, USA, 1996.

[33] C. A. Cambardella and E. T. Elliott, "Carbon and nitrogen dynamics of soil organic matter fractions from cultivated grassland soils," Soil Science Society of America Journal, vol. 58, no. 1, pp. 123-130, 1994.

[34] J. A. Galantini, N. Senesi, G. Brunetti, and R. Rosell, "Influence of texture on organic matter distribution and quality and nitrogen and sulphur status in semiarid pampean grassland soils of Argentina," Geoderma, vol. 123, no. 1-2, pp. 143-152, 2004.

[35] H. Tiessen, J. W. B. Stewart, and A. Oberson, "Innovative soil phosphorus availability indices: assessing organic phosphorus," in Soil Testing: Prospects for Improving Nutrient Recommendations, J. L. Havlin and J. S. Jacobsen, Eds., pp. 143-162, Soil Science Society of America and American Society of Agronomy, Madison, Wis, USA., 1994.

[36] A. M. Urioste, A. M. Bono, D. E. Buschiazzo, G. G. Hevia, and E. N. Hepper, "Fracciones de fósforo en suelos agrícolas y pastoriles de la región semiárida pampeana central (Argentina)," Ciencia del Suelo, vol. 14, no. 2, pp. 92-95, 1996 (Spanish).

[37] R. Baravalle, R. Rosell, A. Miglierina, and P. Maiza, "Soil fixation and availability of phosphate fertilizer," Communications in Soil Science and Plant Analysis, vol. 26, no. 13-14, pp. 2157-2165, 1995.

[38] L. Suñer and J. Galantini, "Dinámica de las formas del P en suelos de la región sudoeste pampeana: estudio de la incubación con fertilizante fosfatado," Ciencia del Suelo, vol. 31, pp. 33-44, 2013 (Spanish).

[39] J. A. Galantini, L. Suñer, and H. Kruger, "Dinámica de las formas de $\mathrm{P}$ en un haplustol de la región semiárida pampeana durante 13 años de trigo continuo," Revista de Investigaciones Agropecuarias, vol. 34, pp. 13-31, 2005 (Spanish).

[40] J. Magid and N. E. Nielsen, "Seasonal variation in organic and inorganic phosphorus fractions of temperate-climate sandy soils," Plant and Soil, vol. 144, no. 2, pp. 155-165, 1992.

[41] J. A. Galantini and R. Rosell, "Long-term fertilization effects on soil organic matter quality and dynamics under different production systems in semiarid pampean soils," Soil and Tillage Research, vol. 87, no. 1, pp. 72-79, 2006. 

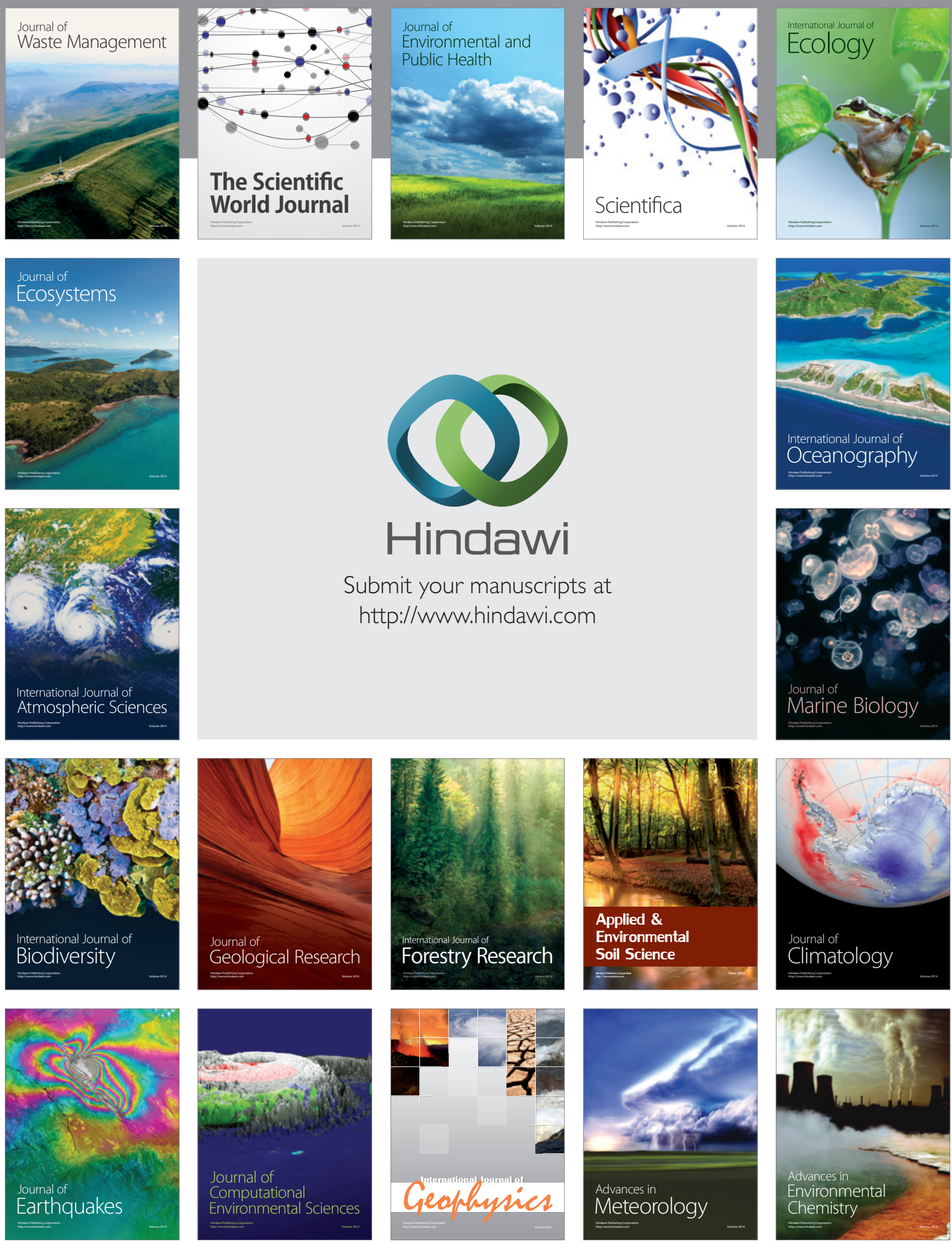